(Final Version)

\title{
Internal versus External R\&D: a Study of R\&D Choice with Sample Selection
}

\author{
James H Love \\ Aston Business School \\ Aston University \\ Birmingham B4 7ET \\ United Kingdom \\ e-mail: j.h.love@aston.ac.uk \\ Stephen Roper \\ School of Management and Economics and \\ Northern Ireland Economic Research Centre \\ Queen’s University Belfast \\ Belfast BT7 1NN \\ United Kingdom \\ e-mail: s.roper@qub.ac.uk
}

Acknowledgement: We are grateful for useful comments received from two anonymous referees, from participants at the Network of Industrial Economists annual conference in Oxford and the $26^{\text {th }}$ EARIE conference in Turin, and at staff seminars in the University of Umeå and University College Cork. 


\title{
Internal versus External R\&D: a Study of R\&D Choice with Sample Selection
}

\begin{abstract}
This paper extends previous analyses of the choice between internal and external R\&D to consider the costs of internal R\&D. The underlying hypothesis is that the choice of R\&D mode is determined by their relative costs. Rather than merely estimating a reduced form probit model for R\&D mode, we employ the Heckman two-stage estimator to estimate the determinants of internal R\&D unit cost (i.e. cost per product innovation) allowing for sample selection effects. Theory indicates that R\&D unit cost will be influenced by scale issues and by the technological opportunities faced by the firm. We also allow for transaction costs arising from the highly uncertain and incomplete nature of contracting encountered in research activities. In addition, consideration is given to issues of market structure which influence the choice of $R \& D$ mode without affecting the unit cost of internal or external R\&D, i.e. factors affecting the likelihood of dissipation of rents accruing from $R \& D$ activity.

The model is tested on data from a sample of over 500 UK manufacturing plants which have engaged in product innovation. The key determinants of $\mathrm{R} \& \mathrm{D}$ mode are the scale of plant and $R \& D$ input, and market structure conditions. In terms of the $R \& D$ cost equation, scale factors are again important and have a non-linear relationship with R\&D unit cost. Specificities in physical and human capital also affect unit cost, but have no clear impact on the choice of R\&D mode. There is no evidence of technological opportunity affecting either R\&D cost or the internal/external decision.
\end{abstract}

Keywords: Scale, Market Structure, Cost of R\&D, R\&D Mode.

JEL codes: D23, L22, O32 


\section{Introduction}

Firms engaged in innovation face two important decisions. First, how much to invest in $\mathrm{R} \& \mathrm{D}$, and second, how to make that investment. A considerable body of research has developed examining the first of these decisions, with the link between $R \& D$ inputs and innovation outputs considered in terms of an innovation production function (e.g. Geroski, 1990; Harris and Trainor, 1995; Love and Roper, 1999). Less well researched is the second important aspect of the $R \& D$ decision; whether to conduct $R \& D$ internally or to fund R\&D conducted elsewhere (i.e. to conduct R\&D externally). The evidence suggests that this is not a trivial issue, and that there are considerable sectoral variations in the extent of external R\&D usage. UK figures for 1993 indicate, for example, that of $£ 7040 \mathrm{~m}$ R\&D spending by UK manufacturing businesses, £846m (12 per cent) was extramural, with this proportion varying by sector from nil to fifty per cent ${ }^{1}$.

The use of external R\&D may have advantages for firms in overcoming the limitations of in-house $R \& D$ budgets and in gaining access to the economies of scale and scope available to specialist research organisations. External R\&D links may also be a useful method of searching the technological environment in a systematic fashion, possibly permitting access to improved technology developed elsewhere (Mowery, 1990; Niosi, 1999). But the external route also has potential disadvantages. Intellectual property rights and appropriability difficulties may make external R\&D unattractive, as may the lack of appropriate expertise of potential contractors compared to those within a firm's own R\&D department. Conversely, under the conditions of asymmetric information which will often prevail in the context of research and innovation, a combination of uncertainty and principal-agent type arguments may make external R\&D seem more attractive, but

\footnotetext{
${ }^{1}$ The extra-mural percentages of total R\&D spending for individual UK manufacturing sectors in 1993 were: Electrical machinery and apparatus, 10.4; Radio, television etc, 4.7; Chemicals, man-made fibres. , 9.1; Pharmaceuticals, 15.3; Refined petroleum products , 32.1; Aerospace, 14.3; Motor vehicles and parts, 21.3; Shipbuilding and repairs, 50.0; Other transport equipment, 17.6; Casting of iron and steel, 4.0; Nonferrous metals, 0.0; Fabricated metal products, 4.2; Precision instruments, 19.9; Office machinery and computers, 4.2; Other machinery, 5.5; Food products and beverages; Tobacco products, 7.9; Textiles, clothing and leather products, 4.5; Rubber and plastic products, 6.0; Other non-metallic mineral products, 3.7; Pulp, paper and paper products; Printing and publishing, 6.1; Furniture; Wood and straw products, 12.5; Other manufactured goods; Recycling, 9.5. (Source: R\&D in UK Business $6^{\text {th }}$ Edition, MO14, Central Statistical Office).
} 
can lead to problems of monitoring as the agent is able to exaggerate the costs and commercial potential of their innovations (Audretsch et al, 1996; Ulset, 1996).

There is an implicit recognition in this research that the optimal internal/external decision or combination will vary for different types and sizes of enterprises as the characteristics of the firm influence the relative costs of each type of R\&D. There is considerable evidence, for example, that $R \& D$ is characterised by diminishing returns to scale (Acs and Audretsch, 1991; Roper, 1997), although we know little about the relative returns to internal and external R\&D. In addition, it is likely that the transaction costs of organising external R\&D will be higher in smaller firms or those that carry out R\&D only on an irregular basis. Small firms, or those in a relatively weak market position, may also find it more difficult to exploit fully the commercial benefits from successful R\&D.

In this paper we draw on the transaction costs literature and on market structure and property rights conditions to provide a framework within which we can examine both the firm-specific and market aspects of the internal/external decision. Our main focus, however, is not on the internal/external decision itself but rather on the factors which determine the productivity (and hence cost) of internal R\&D. In much of the existing empirical research these costs are implicit in reduced form equations for the probability of undertaking internal R\&D (Hertog and Thurik, 1993; Audretsch et al, 1996). Here, using techniques more commonly applied in labour market studies (e.g. Dolton et al, 1989), we are able to estimate an explicit (i.e. structural) model for the determinants of the costs of internal $R \& D^{2}$.

The remainder of the paper is organised as follows. Section 2 outlines a model of the $R \& D$ decision based on the factors that influence both the cost of internal versus external $\mathrm{R} \& \mathrm{D}$, and the market conditions facing establishments. Section 3 describes the dataset used for the empirical analysis, and highlights some key differences between manufacturing plants using internal and external R\&D. In Section 4 the model of R\&D

\footnotetext{
${ }^{2}$ Our analysis does not extend to an examination of the sources of funding for R\&D, nor of the effect that these may have on the internal/external R\&D decision.
} 
choice and internal R\&D cost is estimated for a sample of UK manufacturing plants, and the possible effect of sample selection bias is discussed. Finally, the conclusions are presented. The key findings are that scale and market/appropriability conditions are important determinants of the choice of R\&D mode, and that there is a strong but nonlinear relationship between scale and the unit cost of internal R\&D. Cost is also influenced by specific human assets and the principal production mode of the plant

\section{A Model of the R\&D Decision}

Our starting point here is the recognition that the internal/external decision is similar to other decisions considered in the transaction cost literature on the choice between different institutional forms, particularly the make-or-buy decision ${ }^{3}$. In these models, the choice of institutional form is governed by their relative cost, where costs are defined to include both the 'production' costs of the alternatives as well as the costs of organising and managing the various alternatives. Suppose, for example, that for any anticipated level of innovation outputs the costs of internal $\left(C_{f}\right)$ and external $\left(C_{m}\right) R \& D$ are given by:

$$
\begin{aligned}
& C_{f}=\alpha Z+e \\
& C_{m}=\beta Y+u
\end{aligned}
$$

where $\mathrm{Z}$ and $\mathrm{Y}$ are (non-mutually exclusive) vectors of the determinants of R\&D cost, and $\alpha$ and $\beta$ are coefficient vectors. A typical way to operationalise such a system is to express it as a reduced form probabilistic function ${ }^{4}$, i.e.

$$
\operatorname{Pr}\left(\mathrm{C}_{\mathrm{f}}<\mathrm{C}_{\mathrm{m}}\right)=\operatorname{Pr}(\mathrm{e}-\mathrm{u}<\beta \mathrm{Y}-\alpha \mathrm{Z})
$$

\footnotetext{
${ }^{3}$ See Shelanski and Klein (1995) for a review of such empirical studies.

${ }^{4}$ This assumes that the revenue implications of a given product innovation are invariant to the internal/external decision employed in any particular case.
} 
In terms of the R\&D choice decision equation (2) above is incomplete, and must be extended to allow for exogenous factors that may affect the choice of R\&D mode without affecting the cost of R\&D. For example, there are issues of market structure to consider. An oligopolistic market structure may discourage some firms from engaging in external R\&D involving a partner, for fear of leakage and imitation which could threaten the firms’ property rights over the results of such R\&D. These issues are exogenous to the relative costs of internal and external $R \& D$, so that equation (2) becomes:

$$
\operatorname{Pr}\left(\mathrm{C}_{\mathrm{f}}<\mathrm{C}_{\mathrm{m}}\right)=\operatorname{Pr}(\mathrm{e}-\mathrm{u}<\beta \mathrm{Y}-\alpha \mathrm{Z}-\gamma \mathrm{A})
$$

where A is a vector of factors shaping firms' ability to protect and exploit the property rights arising from the results of its research.

This reduced form can then be estimated by either probit or logit, which is the estimation method favoured by Audretsch et al. However, as Masten et al (1991) point out, this type of reduced form estimation has considerable disadvantages. Perhaps the most important is the impossibility of identifying the structural coefficient vectors (i.e. $\alpha$ and $\beta$ ) from the estimated coefficients of the reduced form model when $\mathrm{Y}$ and $\mathrm{Z}$ share any common elements.

A better approach would be to estimate equations (1.1) and (1.2) as part of a structural system. The difficulty here is that while the cost of internal $R \& D\left(C_{f}\right)$, or more accurately, its unit cost $\left(\mathrm{c}_{\mathrm{f}}\right)$, is usually observable (e.g. as internal $\mathrm{R} \& \mathrm{D}$ expenditure per innovation), the cost of external $R \& D\left(C_{m}\right)$ is generally not observable. This need not prevent estimation of the structural equations, however. The issue is essentially one of selectivity, analogous to the estimation of labour supply functions where wage data are available only for those actually in employment (e.g. Dolton et al, 1989). An appropriate approach is the standard Heckman two-stage model, in which the reduced form probit model of the choice between internal and external $R \& D$ is estimated by substituting the cost equations (1.1) and (1.2) into equation (3). In the second stage, the sample selection term $(\lambda)$ is estimated from this model, and the internal $R \& D$ cost equation (1.1) is 
estimated, now suitably corrected for selectivity where it exists. The key advantage of this procedure is that it permits the identification of differences in the magnitudes and signs of coefficients on the common elements of vectors $\mathrm{Y}$ and $\mathrm{Z}$, differences which are obscured in the reduced form estimation ${ }^{5}$.

The cost of $R \& D$ is best understood in terms of the innovation production function, which requires some suitable measures of the outputs and inputs of such a function. We follow the convention in the industrial organisation literature on the innovation production function by regarding new products - innovations - as the ultimate output of R\&D, with inputs represented by $R \& D$ expenditure. At it simplest, such a production function has the following form (Geroski, 1990):

$$
\mathrm{I}=\gamma \mathrm{R}+\varepsilon
$$

where I is the number of innovations and $\mathrm{R}$ is $\mathrm{R} \& \mathrm{D}$ input. We are therefore concerned with the factors influencing the efficiency with which R\&D inputs are turned into (product) innovation outputs for a given firm. In a comprehensive review of the literature, Hay and Morris (1991, pp 470-1) identify two principal determinants of R\&D productivity: scale of operation, and the 'technological opportunities' of the firm or sector of which it is part.

The most obvious component of scale of operation is the possibility of economies of scale in research, arising from inter alia equipment indivisibilities, and from the ability of larger research operations to recruit more able staff and accept projects which carry higher risks but greater potential rewards. This is measured by total R\&D staff within the plant. In addition, however, there is the possibility that a given level of R\&D expenditure may be more effectively managed by a large than a small firm - the idea that innovation intensity may vary with firm (or plant) size. The evidence, however, suggests that while there is substantial variation in $R \& D$ productivity between plants of different sizes, “...the productivity of R\&D apparently falls along with firm size. There is no evidence

\footnotetext{
${ }^{5}$ In theory, estimation of the structural form also allows the derivation of the implicit coefficients of the external R\&D cost function (See, for example, Maddala, 1983, pp 228-9). In practice, however, the standard errors which attach to these estimates tend to be too large to give meaningful results.
} 
that increasing returns to $R \& D$ expenditures in product innovative output exist. Rather, ... diminishing returns to $R \& D$ are the rule.” (Acs and Audretsch, 1991, p. 57). Moreover, the work of Acs and Audretsch also suggests that the relationship between plant size and R\&D productivity is likely to be non-linear when represented by employment in the plant and its square.

One other factor often thought to influence the productivity of $R \& D$ is whether a plant is part of a larger group within a multi-plant company, an important consideration in plantlevel analysis where there is the possibility of centralisation of group $R \& D$ resources. The extent of any advantage from group membership, however, is likely to be related both to the position of the individual subsidiary within the group and to the strategy of the group in terms of technological development (Birkinshaw and Hood, 1997). Where there is complementarity, in either technological or market terms, between a subsidiary company and the rest of a group, access to group resources may reduce the net cost of internal R\&D. If, however, subsidiaries possess 'unique technical capabilities' or they are product specialists, group membership is less likely to be an important $R \& D$ cost determinant (Egelhoff et al, 1998). In the empirical analysis we include a dummy variable that takes value 1 if the plant is a member of a wider multi-national group of companies and zero otherwise.

The concept of technological opportunity is more difficult to operationalise, except to make the general point that important differences exist between the average $R \& D$ intensity of individual sectors. In 1993, for example, R\&D spending varied from 21.0 per cent of sales in the UK pharmaceuticals sector to 0.1 per cent of sales in the paper and paper products and furniture sectors ${ }^{6}$. More subtly, the work of Audretsch and Feldman (1996) and Jaffe (1986) indicates that there can be important positive spillover effects from the research of others firms which are in geographical and technological proximity, effects which enhance the $R \& D$ productivity and hence lower the unit cost of the individual establishment's own research efforts. In the empirical analysis technological

\footnotetext{
${ }^{6}$ Source: Research and Development in UK Business $6^{\text {th }}$ Edition, MO14, Central Statistical Office, Table 26, p. 51 .
} 
opportunity is proxied by the average sectoral $R \& D$ intensity (i.e. $R \& D$ employment as a proportion of total employment).

From this discussion of $R \& D$ productivity it is but a short step to the internal $R \& D$ cost function (equation 1.1). From the innovation production function described above, productivity is the number of innovations per unit of R\&D input. An obvious measure of $\mathrm{C}_{\mathrm{f}}$, the total cost of internal $\mathrm{R} \& \mathrm{D}$, is therefore total firm expenditure on $R \& D$; since the ultimate output of $R \& D$ is innovation, unit cost can therefore be expressed as $R \& D$ expenditure per product innovation.

There is, however, a further set of costs which are directly relevant to the decision on which form of R\&D the firm is most likely to adopt. These are the transaction costs involved in managing internal $R \& D$ versus those incurred in engaging in contractual research agreements with other parties. The literature on transaction costs emphasises the problems of bargaining and of incomplete contracts in market transacting, with considerable weight being given to the existence of appropriable quasi-rents which may arise from transaction-specific investments under conditions of uncertainty (Klein, Crawford and Alchian, 1978; Williamson, 1979). By their very nature, contracts involving $\mathrm{R} \& \mathrm{D}$ tend to be highly incomplete because of the uncertainty of the research process, and may be characterised by substantial investment in both physical and human specific capital. Teece (1988) highlights the problem of 'lock-in' under these conditions: because of the tacit knowledge acquired by a contracting party in any external R\&D arrangement, there may be very high transaction costs to incur should the other party seek to terminate the contract for reasons of under-performance. What is more, the highly uncertain nature of $R \& D$ makes satisfactory contract completion difficult to define, possibly leading to a preference for internal over external $R \& D$ even where rent-seeking opportunism is not a major threat (Love, 1997). This view is supported by Audretsch et al (1996) who find evidence that the existence of firm-specific human capital is negatively related to the use of external $R \& D$. In the estimation, indicators of the predominant type of production method in the establishment are used to proxy the degree 
of capital specificity in the plant while the proportion of graduate employees proxies the specificity of the firm’s human capital.

The implied form of the internal unit cost equation is therefore as follows (definitions in Table 1):

$\mathrm{C}_{\mathrm{f}}=\beta_{0}+\beta_{1}$ Rdemp $+\beta_{2}$ Size $+\beta_{3}$ Srdint $+\beta_{4}$ Grads $+\beta_{5}$ Sbatch $+\beta_{6}$ Lbatch $+\beta_{7} \mathrm{MNE}+\mu$

Following the discussion above, the sign expectation on the coefficients are $\beta_{3}, \beta_{5}, \beta_{6}$, $\beta_{7}<0, \beta_{4}>0$. Following the discussion above regarding the effects of scale on unit R\&D cost, $\beta_{1}, \beta_{2}<0$ implies economies of scale $\beta_{1}, \beta_{2}>0$ implies diseconomies of scale.

[Table 1 here]

Equation (5) is the estimating version of equation (1.1). In order to derive an estimating version of the reduced-form probit equation (3) we consider factors which, although they do not necessarily influence the relative costs of the internal and external modes, nevertheless exert a direct influence on the choice between internal and external R\&D. These issues revolve around a firm's ability to protect and exploit the property rights arising from the results of its research. All firms have reason to fear the possible dissipation of rents which may result from disclosure of R\&D findings by a research partner or subcontractor, especially where the research is tacit knowledge embedded in individuals (Teece, 1988). However, this will be more of an issue for some firms than for others. In order to protect their favourable positions, firms in highly concentrated markets, especially those firms which themselves have a high market share, will be particularly keen to prevent or delay the imitation by rivals which often accompanies innovation. One way of doing this is to carry out research in-house, lessening the risk of disclosure to rivals. As Hertog and Thurik (1993) state, "Internal R\&D may give a firm a valuable lead time over its rivals in a concentrated market” (p. 283). The same study finds evidence that in Dutch manufacturing high levels of sectoral concentration are 
associated with a low relative incidence of external R\&D at the firm level ${ }^{7}$. Finally, there is the issue of firm growth, with the hypothesis that high-growth firms are less likely to collude, and so are more likely to engage in internal R\&D (Hertog \& Thurik, p. 284). In the estimation, measures of industrial concentration, minimum efficient scale, and the market share and growth rate of the individual plant represent market conditions which directly influence the choice of R\&D mode. The estimating version of equation (3) is thus:

$$
\begin{array}{r}
\operatorname{Pr}(\text { Internal })=\lambda_{0}+\lambda_{1} \text { Rdemp }+\lambda_{2} \text { Size }+\lambda_{3} \text { Srdint }+\lambda_{4} \text { Grads }+\lambda_{5} \text { Sbatch } \\
+\lambda_{6} \text { Lbatch }+\lambda_{7} \text { MNE }+\lambda_{8} \text { CR } 5+\lambda_{9} \text { MES }+\lambda_{10} \text { Share }+\lambda_{11} \text { Growth }+\sigma
\end{array}
$$

The expected coefficient signs on the additional variables are $\lambda_{8}, \lambda_{9}, \lambda_{10}, \lambda_{11}>0$.

\section{Data}

The main plant level data source used in the estimation is the Product Development Survey (PDS) which was originally conducted in 1995. This sought information on various aspects of $\mathrm{R} \& \mathrm{D}$ and product innovation from over 8,300 UK manufacturing businesses, selected to be representative of the size and sectoral distribution of UK manufacturing ${ }^{8}$. The final response rate was $20.6 \%$, giving a usable sample of 1,722 plants. Of these plants, 968 (56 per cent) had introduced at least one new or improved product in the previous three years and were regarded as 'innovators'. Respondents to the PDS also provided information on R\&D expenditure and employment in 1993 and indicated whether R\&D was conducted in-plant.

\footnotetext{
${ }^{7}$ A similar negative, albeit weak , relationship between industry concentration and external R\&D is also reported by Audretsch et al (see, in particular, their estimated coefficients on the concentration ratio terms). 8 An indication of the representativeness of the survey was obtained by comparing survey-based and official figures on UK R\&D employment. In 1993, the official estimates of R\&D employment in UK manufacturing was 119,000 (2.8\% of the workforce); evidence from the PDS suggested a figure of 117,000. Full details of the survey, and descriptive findings, can be found in Roper et al (1996).
} 
Analysis of this type involves comparing the output of R\&D across plants and across industries. These may vary widely in terms of the technological sophistication of each innovation, their degree of originality (i.e. product improvements versus fundamentally new products), and in terms of the revenue impact on the plant making the innovation. Commenting on the problems inherent in this, Hall (1994) argues:

"We should separate product from process innovations and identify those which are major departures as opposed to modest modifications. But this always involves subjective judgement and may ignore the crucial difference between innovations of major economic importance but little technological novelty, or of great technological achievement but little economic value.” (p. 151)

The latter part of Hall's argument is of considerable importance, especially given the evidence from Audretsch (1995) that almost 90\% of commercially significant innovations in the United States involve little or no technological advance. The present study expressly views innovation as a business phenomenon rather than a technological phenomenon. The term 'innovation' is therefore restricted to product innovations, meaning new or improved products which were potentially of some commercial significance to the responding plant. In terms of Hall's quotation above, we have therefore erred on the side of 'economic importance but little technological novelty', on the grounds that we are principally concerned with the economics rather than the technology of new product development and $\mathrm{R} \& \mathrm{D}$ modal choice. The analysis is restricted to innovating plants: the innovation decision is not explicitly modelled ${ }^{9}$.

Analysis carried out at the plant level rather than the firm level has some advantages. Although strategic decisions are likely to be carried out at firm level, they are implemented at the level of the individual plant, and are likely to be based on the product market situation faced by those individual plants. This is especially true of large multiproduct enterprises. Thus a firm may choose to use an internal R\&D strategy at one plant and an external R\&D strategy at another in a different product division which is facing a

\footnotetext{
${ }^{9}$ See Love and Roper (1999) for an estimation of the innovation determinants for this data set. The empirical analysis excludes those plants which undertook R\&D but produced no innovations during the period in question. These plants account for $6.8 \%$ of the total sample.
} 
quite different set of market circumstances, a subtlety which may be missed in firm-level analysis. The possibility that there may be beneficial R\&D spillovers from being a member of a group is nevertheless explicitly allowed for in the MNE dummy, while the sectoral R\&D intensity variable allows for the variations in technological opportunity effects inherent in cross-sectional analysis.

Table 2 summarises the basic PDS data for plants undertaking external R\&D only and those undertaking internal R\&D either with or without external $R \& D^{10,11}$. Although not directly comparable, the proportion of companies undertaking external R\&D only $(9.3$ per cent) is relatively similar to the external proportion (12 per cent) of all UK manufacturing R\&D in 1993.

[Table 2 here]

Plants undertaking only external $R \& D$ were on average significantly smaller than those having some internal R\&D, in terms of both employment and market share (Table 2). This size difference may simply reflect the general tendency for larger firms to undertake more R\&D (Audretsch, 1995; Love and Roper, 1999) but it may also reflect the tendency for larger plants to incorporate additional transactions internally (Audretsch et al, 1996). On average, plants undertaking some R\&D internally had 14 R\&D staff although, as the large standard deviation suggests, plants' level of R\&D employment varied widely. It is also likely that the existence of internal R\&D in this group of plants accounts, at least in part, for their higher level of graduate employment.

In other respects, such as growth performance, the type of production undertaken, sectoral concentration and industry MES, there was relatively little difference between the two groups. Notably, however, the proportion of each group of plants that were part

\footnotetext{
${ }^{10}$ The reason for presenting the data in this way is a consequence of the dependent variable used in the probit estimation, and discussed in the next section.

${ }^{11}$ Analysis is restricted to those 507 innovating plants which provided full information on all estimating variables. On all variables except employment, Mann-Whitney $U$ tests indicate that the sample firms were statistically indistinguishable from the remaining 461 innovators which provided partial information (mean values of 263 and 300 employees respectively).
} 
of MNEs was slightly higher for those undertaking external only (21 per cent) than for those undertaking some internal $R \& D$ (17 per cent). This suggests that on balance the traditional view of the MNE where R\&D is a centralised activity still predominates over the more decentralised strategy envisaged in the literature on subsidiary development (Birkinshaw and Hood, 1998). This is important from the point of view of innovation in that the evidence suggests that lack of an internal $R \& D$ capacity is likely to reduce plants' capacity to innovate. Indeed, as Love and Roper (1999) point out, once the positive influences of technology transfer, networking and larger average size are accounted for, foreign-owned plants in the UK are less innovative than their Britishowned equivalents.

Sectoral R\&D intensity also differed substantially between the two groups with plants in more innovation intensive industries less likely to rely on external R\&D (Table 2). This is consistent with the results of Audretsch et al (1996) and Veugelers (1997) which suggested that in Dutch high-tech industries internal R\&D was necessary, and seen as complementary to external R\&D. In low-tech industries, Audretsch et al suggest that external R\&D may act as a substitute for internal R\&D activity. In summary, only around a tenth of R\&D performing plants in the sample rely on external R\&D only. These plants tend to be smaller, concentrated in less R\&D intensive sectors, and more likely to be part of MNEs than those plants also undertaking internal R\&D.

The mean value of $R \& D$ unit cost (i.e. average cost per innovation) among those plants employing internal R\&D was $£ 55,946$. However, the distribution is highly skewed, with one third of responding plants having unit costs of less than $£ 5000$, and half having unit costs of less than $£ 10,000$. Less than $12 \%$ of sample firms had average $R \& D$ costs per innovation above $£ 100,000$.

\section{Model Estimation}

Our initial aim was to identify those factors that are important in determining plants' 'make or buy' decision in terms of R\&D as a input into the subsequent modelling of the 
cost of internal $R \& D$. For plants undertaking some $R \& D$, there are three possible options; internal only, external only or a combination of both internal and external R\&D. Initial modelling using multinomial choice models indicated that there were no statistical differences between plants undertaking only internal R\&D and those undertaking both internal and external R\&D. ${ }^{12}$ This permitted the use of a simpler modelling approach with a binary dependent variable reflecting the groupings in Table 2, i.e. an internal/external-only split where the 'internal' grouping includes a number of plants which were also undertaking both types of R\&D. 'External' is here defined as a situation in which all of a plant's $R \& D$ activities were carried out either by arm's length contractual agreement or by collaborative agreement which involved no direct use of R\&D staff at the plant in question. ${ }^{13}$

Table 3 reports a number of Probit models of the internal/external-only decision. In all cases the overall $\chi^{2}$ is highly significant, and the ability of the probit estimates to distinguish between the two groups is very high, correctly predicting on average $89 \%$ of external R\&D-only plants and 98\% of internal R\&D plants. There is a strong relationship between plant size, numbers of $R \& D$ staff, and the choice of $R \& D$ mode. This relationship is complex, however, with the probability that a plant will engage in some internal R\&D varying quadratically with respect to R\&D employment and in cubic fashion with respect to plant size. In terms of plant size, this suggests ceteris paribus that the probability that a plant will have internal $R \& D$ declines until reaching a turning point at 627 employees and then increases until the second turning point at around 5600 employees $^{14}$. This plant size effect is offset, however, by a similar but inverse effect relating to the plant's number of R\&D employees ${ }^{15}$. We read little into the latter result: it

\footnotetext{
${ }^{12}$ See Veugelers and Cassiman (1999: 75) for a similar discussion in relation to Belgian data.

${ }^{13}$ Note that this definition of 'external' excludes R\&D carried out by another plant within the same firm: the vast majority of plants which did have such a relationship also had some internal R\&D capacity and/or had external R\&D links. Group spillover effects are allowed for by the MNE dummy.

${ }^{14}$ Both of these turning points are within the observed range for the sample, as are the turning points for R\&D employment discussed below.

${ }^{15}$ The turning point implied by the coefficients on R\&D employment (637) is very similar to that of the plant size coefficients. This means that the vast majority of plants in the sample, which have less than 637 R\&D staff, are operating on that portion of the curve which implies an increasing probability of internal $R \& D$ as $R \& D$ employment increases. This suggests that the probability of a plant engaging in some
} 
should be borne in mind that firms undertaking only external R\&D have, by definition, no $R \& D$ employees, and this variable is included principally for the estimated cost equation which follows. Other plant-level variables included in the probit models perform poorly, with graduate numbers, and type of production having little effect on the probability that the plant will undertake some $R \& D$ internally. There is also little evidence, from the estimated coefficients on sectoral R\&D intensity, that the extent of technological opportunity in a plants' industry has any significant effect on its choice of R\&D mode.

[Table 3 here]

More interesting are the coefficients on the measures of industry concentration (CR5), minimum efficient scale (MES) and market share, designed to capture plants' ability to exploit the benefits of innovation outputs. Market concentration has a significant effect, increasing the probability that a plant will undertake some R\&D internally. The negative and significant coefficient on MES may at first seem surprising. However, the ComanorWilson proxy is positively related to industry size inequalities; in conjunction with the CR5 result, this implies that firms in highly concentrated sectors where the size distribution of competitors is fairly equal are more likely to favour internal $R \& D$, in line with concerns over property rights under such conditions. High plant market share also increases the likelihood of internal R\&D.

In general, these results suggest that the choice of $R \& D$ mode in UK manufacturing is dominated by scale and market structure effects. The internal characteristics of the plant and its potential relationship to other group plants seem relatively unimportant. Hertog and Thurik (1993), who use a range of industry level explanatory variables in their analysis, reach essentially similar conclusions, although Audretsch et al (1996) do identify significant effects on R\&D mode from plants' capital intensity and the skill composition of their workforce.

internal R\&D varies quadratically with $R \& D$ intensity itself, increasing initially before falling beyond the 637 employee turning point. 
The significance of plant scale and market structure on the choice of $R \& D$ mode suggests the possibility of self-selection in terms of the group of companies undertaking internal $R \& D$. If this element of selectivity is significant, direct estimation of an internal $R \& D$ cost equation is likely to lead to biased results (see for example, Greene, 1997, p. 982). It is therefore necessary to allow explicitly for the possibility of some selection bias in the estimation of the internal R\&D cost equation (see Maddala, 1983, pp 257-290 for a general discussion). This is done using the Heckman two-stage estimator, and Table 4 reports four such models estimated for those plants undertaking some internal R\&D (i.e. taking the value 1 in the probit equations in Table 3 ), where the dependent variable is $R \& D$ unit cost (i.e. the ratio of total $R \& D$ spending to the number of product innovations).

\section{[Table 4 here]}

The key finding is once again the importance of scale, both in terms of plant size and in terms of numbers of R\&D staff: internal R\&D unit costs increase with both plant size and the scale of plants' R\&D operation. As before, however, these relationships are nonlinear with the effect of plant size on R\&D unit costs starting to fall beyond 780 employees, and the effect of $R \& D$ scale on $R \& D$ unit cost starting to fall beyond 870 R\&D employees. Our results for plant size parallel much other recent work which suggests that there is a quadratic or inverse relationship between innovation intensity and firm/plant size (Acs and Audretsch, 1988; Love and Roper, 1999), and that diminishing returns to R\&D are prevalent over a wide range of firm sizes (Acs and Audretsch, 1991). Taken together with the Probit results, this suggests an interesting pattern with respect to internal R\&D (cost) and plant size. Once a threshold plant size of around 630 employees is reached, increased plant size increases the likelihood of internal $R \& D$; however, initially this is at a sub-optimal level with diseconomies of scale. Only once the higher plant-size threshold of 780 employees is reached are scale economies achieved in terms of effective management of research projects. 
In terms of scale economies arising directly from the scale of plants' R\&D operations (i.e. equipment indivisibilities, acceptance of higher-risk projects etc.), the estimated coefficients for R\&D personnel indicate that achieving falling unit cost involves crossing a very high personnel threshold of over 800, an investment so large for the individual plant or firm that economies will be achieved by only a tiny proportion of all plants. Some care should be taken in interpreting the results for R\&D personnel, because these data refer to total R\&D employment, while the dependent variable relates only to product innovation. This may have resulted in some upward bias in the threshold required to achieve scale economies in terms of R\&D personnel, although the extent of any such bias is uncertain

Unlike the Probit equations for the probability of undertaking internal $R \& D, R \& D$ unit cost is influenced relatively strongly by other plant characteristics. A higher proportion of graduates in the workforce, for example, has a positive effect on internal $R \& D$ unit costs. This implies that in terms of cost per innovation, graduate employees are more expensive than other employee groups. The production characteristics of the plant also have a significant impact on R\&D unit cost, with dummy variables for both small and large batch production having consistent negative effects relative to plants undertaking continuous production. Despite the hypothesis that capital-intensive plants are more likely to engage in external $R \& D^{16}$, it may not appear obvious that there is any immediate link between plants' production operations and the cash cost of internal R\&D. In the estimation, however, we measure R\&D unit cost per new product or product change. As continuous production systems tend to be inflexible relative to batch oriented production systems, product changes may be less costly and more frequent in the latter type of production system, thus reducing $R \& D$ unit cost.

The internal R\&D cost equations suggest three other points. First, the positive coefficient on the sectoral R\&D intensity variable provides no support for the hypothesis that $R \& D$ cost in a plant will be reduced by spillover effects from R\&D undertaken by other firms

\footnotetext{
${ }^{16}$ Because capital-intensive plants are more likely to produce relatively standardised products that can only be copied with difficulty by imitators (Audretsch et al, 1996).
} 
within the sector. Secondly, the coefficients on the group/MNE dummy vary in sign and are statistically insignificant suggesting that any 'internal' spillover effects on R\&D cost are minimal. The insignificance of this coefficient is potentially important, as this dummy variable is designed to offset (at least partially) any distortion of the R\&D figures induced by the study being plant rather than firm based. Thirdly, despite the apparent potential for selectivity effects noted earlier, the sample selection parameter $(\lambda)$ is consistently insignificant. This suggests that there is no bias in the estimates of $R \& D$ cost arising from the fact that not all plants perform R\&D internally, and that OLS estimation of R\&D unit cost can safely be undertaken. As would be anticipated under these circumstances, the OLS results are very similar to those of the sample selection models (Table 5).

[Table 5 here]

\section{Conclusions}

The purpose of this paper is to go beyond the simple reduced-form estimation of the choice between internal and external $R \& D$ and examine the underlying costs of internal R\&D. The analysis was informed by the literature on scale and technological opportunity as determinants of the cost of $\mathrm{R} \& \mathrm{D}$, and by issues of property rights and transaction costs developed from the new institutional economics literature. Clearly there are limitations in performing cross-sectional analysis of this type. For example, the relationship between $R \& D$ expenditure and innovation is likely to have a time component, with the stock as well as the flow of R\&D having some effect. Nevertheless, there are consistent and robust results arising from the econometric estimation.

One of the key findings is that relationship between scale and the internal/external R\&D decision is quite complex, much more so than is suggested by the analysis of e.g. Hertog and Thurik (1993) who are able to conclude only that small enterprises are more likely to engage in external $R \& D$. Our results indicate that this decision is mediated through the relationship between size, $R \& D$ inputs and $R \& D$ unit cost, and that this relationship is non-linear. In order to achieve economies of scale in internal R\&D, plants need not only 
be of beyond medium size, but employ a very large complement of research staff in situ. As indicated in the previous section, the scale coefficients must be interpreted with caution, but our results do complement previous research which finds that decreasing returns to scale are common in R\&D (Acs and Audretsch, 1991). Although we are in no position to determine why this is the case over such a wide range of R\&D inputs, one obvious possibility relates to the nature of the $R \& D$ function itself. $R \& D$ covers a wide range of activities from fundamental research to relatively routine development work. Conceivably, the relatively high risk basic research is being undertaken in a relatively few large plants which have the research and financial capacity to do so, while most other plants carry out mainly development work. Since basic research carries greater risk of failure (in terms of no innovative output) this may lead to larger plants effectively appearing to have relatively higher $\mathrm{R} \& \mathrm{D}$ unit costs, especially when innovation is defined broadly as in the present study. This would also help explain the pattern found here and in much previous research of an inverse relationship between plant/firm size and innovation intensity (i.e. innovations per employee).

The empirical results also strongly suggest that, regardless of the internal $R \& D$ cost conditions faced by the individual plant, market structure conditions have an important role to play in the organisation of $R \& D$. Plants with a relatively high market share operating in concentrated industrial sectors are more likely to maintain an internal R\&D capacity, especially where size inequalities are modest and so rivalry may be expected to be intense. This is in line with the hypothesis that plants experiencing these conditions are particularly keen to protect the property rights arising from their research, which might otherwise be dissipated where collaboration is employed. Specificities in physical and human capital also affect unit cost, but have no clear impact on choice of R\&D mode. We find no clear evidence of technological opportunity affecting R\&D cost or the internal/external decision. 
.Table 1: Variables in Unit Cost and R\&D Mode Equations

\begin{tabular}{lll}
\hline Variable & Definition & Source \\
\hline $\mathrm{C}_{\mathrm{f}}$ & R\&D expenditure per innovation & Survey \\
Rdemp & R\&D staff (number) & Survey \\
Size & Plant employment & Survey \\
Srdint & Sectoral R\&D intensity & Weighted average of plant \\
& & R\&D/employment ratios (3-digit level) \\
Grads & Graduates in employment (\%) & Survey \\
Sbatch & Small batch production dummy & Survey \\
Lbatch & Large batch production dummy & Survey \\
MNE & MNE group plant dummy & Survey \\
CR5 & 5-firm concentration ratio & Census of Production (3-digit level) \\
MES & Comanor-Wilson MES proxy & Census of Production (3-digit level) \\
Share & Plant market share & Survey and Census of Production \\
Growth & Plant sales growth & Survey \\
\hline
\end{tabular}


Table 2: Descriptive Statistics

\begin{tabular}{lrrrrr}
\hline & \multicolumn{2}{c}{$\begin{array}{c}\text { External } \\
\text { R\&D Only }\end{array}$} & \multicolumn{2}{c}{$\begin{array}{c}\text { Internal } \\
\text { R\&D }\end{array}$} \\
& \multicolumn{2}{c}{$\mathrm{N}=47$} & $\mathrm{~N}=460$ \\
\hline & Mean & S.D. & Mean & S.D. \\
A. R\&D Cost Factors & & & & \\
R\&D expenditure per innovation (£000) & 0.00 & 0.00 & 55.94 & 172.17 \\
Plant Size (employment) & 211.23 & 271.38 & 268.19 & 829.60 \\
R\&D Staff (number) & 0.00 & 0.00 & 14.39 & 79.88 \\
Sectoral R\&D Intensity & 2.97 & 2.95 & 3.47 & 2.59 \\
Graduate Share of Workforce (\%) & 6.51 & 6.23 & 8.88 & 9.89 \\
Small Batch Production (\%) & 0.53 & 0.50 & 0.56 & 0.50 \\
Large Batch Production (\%) & 0.28 & 0.45 & 0.34 & 0.47 \\
MNE plant (\%) & 0.21 & 0.41 & 0.17 & 0.38 \\
& & & & & \\
& & & & & \\
B. Structure Indicators & & & & & \\
Market Share & 0.45 & 0.81 & & 0.72 & 2.51 \\
Five-firm Concentration Ratio & 29.86 & 18.34 & 30.60 & 18.25 \\
Minimum Efficient Scale Indicator & 1.81 & 2.47 & 1.65 & 2.07 \\
Turnover Growth & 0.09 & 0.20 & 0.08 & 0.18 \\
\hline
\end{tabular}


Table 3: Binomial Probit Models for Undertaking Internal R\&D

\begin{tabular}{|c|c|c|c|c|c|}
\hline & (1) & $(2)$ & $(3)$ & (4) & \\
\hline Constant & $\begin{array}{r}-0.837 \\
(0.659)\end{array}$ & $\begin{array}{r}-0.956 \\
(0.696)\end{array}$ & $\begin{array}{l}-0.839 \\
(0.661)\end{array}$ & $\begin{array}{r}-0.783 \\
(0.663)\end{array}$ & \\
\hline \multicolumn{6}{|l|}{ A. R\&D Cost Determinants } \\
\hline R\&D Employment & $\begin{array}{l}3.072 \text { ** } \\
(0.531)\end{array}$ & $\begin{array}{l}3.169 \text { ** } \\
(0.544)\end{array}$ & $\begin{array}{l}3.081 \text { ** } \\
(0.534)\end{array}$ & $\begin{array}{r}3.103 \\
(0.544)\end{array}$ & ** \\
\hline R\&D Employment Squared & & $\begin{array}{l}-24.897 * * \\
(4.411)\end{array}$ & $\begin{array}{l}-24.168 \text { ** } \\
(4.324)\end{array}$ & & \\
\hline Plant Size (Empl) & $\begin{array}{l}-0.019 \text { ** } \\
(0.006)\end{array}$ & $\begin{array}{l}-0.021 \text { ** } \\
(0.006)\end{array}$ & $\begin{array}{l}-0.019 \text { ** } \\
(0.006)\end{array}$ & $\begin{array}{r}-0.0205 \\
(0.006)\end{array}$ & ** \\
\hline Plant Size Squared & $\begin{array}{l}0.151 \text { ** } \\
(0.050)\end{array}$ & $\begin{array}{l}0.165 \text { ** } \\
(0.053)\end{array}$ & $\begin{array}{l}0.151 \text { ** } \\
(0.051)\end{array}$ & $\begin{array}{r}0.181 \\
(0.059)\end{array}$ & ** \\
\hline Plant Size Cubed & & & & $\begin{array}{r}-0.002 \\
0.001\end{array}$ & ** \\
\hline Sectoral R\&D Intensity & $\begin{array}{l}-0.037 \\
(0.129)\end{array}$ & $\begin{array}{l}-0.023 \\
(0.129)\end{array}$ & $\begin{array}{l}-0.037 \\
(0.129)\end{array}$ & $\begin{array}{r}-0.039 \\
(0.130)\end{array}$ & \\
\hline Graduate Share Of Workforce & $\begin{array}{r}0.058 \\
(0.039)\end{array}$ & $\begin{array}{l}0.0505 \\
(0.039)\end{array}$ & $\begin{array}{r}0.057 \\
(0.039)\end{array}$ & $\begin{array}{r}-0.060 \\
(0.039)\end{array}$ & \\
\hline Small Batch Production & $\begin{array}{r}-0.561 \\
(0.459)\end{array}$ & $\begin{array}{l}-0.539 \\
(0.459)\end{array}$ & $\begin{array}{l}-0.561 \\
(0.459)\end{array}$ & $\begin{array}{r}-0.591 \\
(0.463)\end{array}$ & \\
\hline Large Batch Production & $\begin{array}{l}-0.431 \\
(0.448)\end{array}$ & $\begin{array}{l}-0.286 \\
(0.462)\end{array}$ & $\begin{array}{l}-0.431 \\
(0.449)\end{array}$ & $\begin{array}{l}-0.456 \\
(0.452)\end{array}$ & \\
\hline MNE Plant & & $\begin{array}{r}0.664 \\
(0.595)\end{array}$ & & & \\
\hline B. Structure Indicators & & & & & \\
\hline Concentration Ratio (CR5) & $\begin{array}{l}0.069 \text { ** } \\
(0.025)\end{array}$ & $\begin{array}{l}0.071 \text { ** } \\
(0.025)\end{array}$ & $\begin{array}{l}0.070 \text { ** } \\
(0.025)\end{array}$ & $\begin{array}{r}0.071 \\
(0.025)\end{array}$ & ** \\
\hline Minimum Efficient Scale & $\begin{array}{l}-0.494 \text { ** } \\
(0.193)\end{array}$ & $\begin{array}{l}-0.511 \\
(0.196)\end{array}$ & $\begin{array}{l}-0.495 \text { ** } \\
(0.193)\end{array}$ & $\begin{array}{l}-0.501 \\
(0.195)\end{array}$ & ** \\
\hline Market Share & $\begin{array}{l}0.753 \text { ** } \\
(0.371)\end{array}$ & $\begin{array}{l}0.838 \text { ** } \\
(0.384)\end{array}$ & $\begin{array}{l}0.754 \text { ** } \\
(0.372)\end{array}$ & $\begin{array}{r}0.771 \\
(0.376)\end{array}$ & ** \\
\hline Turnover Growth & $\begin{array}{r}-0.906 \\
(0.812)\end{array}$ & $\begin{array}{l}-0.831 \\
(0.843)\end{array}$ & $\begin{array}{l}-0.907 \\
(0.813)\end{array}$ & $\begin{array}{r}-0.957 \\
(0.818)\end{array}$ & \\
\hline $\mathrm{N}$ & 507 & 507 & 507 & 507 & \\
\hline Log Likelihood & -29.40 & -28.69 & -29.35 & -29.29 & \\
\hline Equation $\chi^{2}()$. & 254.26 & 255.67 & 254.35 & 254.48 & \\
\hline
\end{tabular}

Note: The dependent variable equals one when the firm engages in internal $R \& D$ regardless of whether or not it engages in any additional external R\&D. Figures in brackets are standard errors. ${ }^{* *}$ denotes that a coefficient is significant at the five percent level. * denotes significance at the 10 per cent level. 
Table 4: Sample Selection Models for the Unit Cost of Internal R\&D

\begin{tabular}{|c|c|c|c|c|}
\hline & (1) & (2) & (3) & (4) \\
\hline Constant & $\begin{array}{l}-33.423 \text { * } \\
(19.884)\end{array}$ & $\begin{array}{r}-5.584 \\
(18.711)\end{array}$ & $\begin{array}{r}-4.622 \\
(18.574)\end{array}$ & $\begin{array}{r}-8.114 \\
(21.665)\end{array}$ \\
\hline R\&D Employment & $\begin{array}{l}1.032 \text { ** } \\
(0.153)\end{array}$ & $\begin{array}{l}4.595 \text { ** } \\
(0.474)\end{array}$ & $\begin{array}{l}4.580 \text { ** } \\
(0.472)\end{array}$ & $\begin{array}{l}1.266 \text { ** } \\
(0.172)\end{array}$ \\
\hline R\&D Employment Squared & & $\begin{array}{l}-26.48 \text { ** } \\
(3.379)\end{array}$ & $\begin{array}{c}-26.316 \\
(3.35)\end{array}$ & \\
\hline Plant Size (Empl) & $\begin{array}{l}0.384 \text { ** } \\
(0.051)\end{array}$ & $\begin{array}{l}0.215 \text { ** } \\
(0.053)\end{array}$ & $\begin{array}{l}0.221 \\
(0.051)\end{array}$ & $\begin{array}{r}0.157 \\
(0.101)\end{array}$ \\
\hline Plant Size Squared & $\begin{array}{l}-1.593 \\
(0.261)\end{array}$ & $\begin{array}{l}-1.391 \\
(0.247)\end{array}$ & $\begin{array}{l}-1.412 \\
(0.241)\end{array}$ & $\begin{array}{r}1.379 \\
(1.132)\end{array}$ \\
\hline Plant Size Cubed & & & & $\begin{array}{l}-0.086 \text { ** } \\
(0.031)\end{array}$ \\
\hline Sectoral R\&D Intensity & $\begin{array}{l}6.787 \text { ** } \\
(3.116)\end{array}$ & $\begin{array}{r}2.910 \\
(2.902)\end{array}$ & $\begin{array}{r}2.844 \\
(2.897)\end{array}$ & $\begin{array}{l}6.006 \text { * } \\
(3.095)\end{array}$ \\
\hline Graduate Share & $\begin{array}{l}2.827 \\
(0.806)\end{array}$ & $\begin{array}{l}1.755 \text { ** } \\
(0.75)\end{array}$ & $\begin{array}{c}1.768 \text { ** } \\
(0.750)\end{array}$ & $\begin{array}{l}2.745 \text { ** } \\
(0.797)\end{array}$ \\
\hline Small Batch Production & $\begin{array}{r}-20.951 \\
(16.687)\end{array}$ & $\begin{array}{l}-26.514 \\
(15.329)\end{array}$ & $\begin{array}{l}-26.862 \text { * } \\
(15.302)\end{array}$ & $\begin{array}{r}-24.989 \\
(16.567)\end{array}$ \\
\hline Large Batch Production & $\begin{array}{l}-52.996 \\
(17.872)\end{array}$ & $\begin{array}{c}-56.51 \\
(16.408)\end{array}$ & $\begin{array}{l}-56.905 \\
(16.378)\end{array}$ & $\begin{array}{l}-53.542 \\
(17.693)\end{array}$ \\
\hline MNE Plant & & $\begin{array}{r}6.958 \\
(19.269)\end{array}$ & & $\begin{array}{r}-1.776 \\
(20.934)\end{array}$ \\
\hline$\lambda$ & $\begin{array}{r}-44.410 \\
(57.512)\end{array}$ & $\begin{array}{r}-10.053 \\
(51.711)\end{array}$ & $\begin{array}{r}-12.625 \\
(53.283)\end{array}$ & $\begin{array}{r}-31.733 \\
(57.284)\end{array}$ \\
\hline $\mathrm{N}$ & 326 & 326 & 326 & 326 \\
\hline$F()$. & 25.32 & 29.92 & 33.33 & 21.36 \\
\hline Log Likelihood & -2055.4 & -2026.0 & -2026.6 & -2050.5 \\
\hline
\end{tabular}

Note: The dependent variable is the unit cost of internal R\&D, i.e. the cost of internal R\&D per product innovation. Estimation is restricted to those companies undertaking internal R\&D only. Figures in brackets are standard errors. ** denotes that a coefficient is significant at the five percent level. * denotes significance at the 10 per cent level. 
Table 5: OLS Regressions for the Unit Cost of Internal R\&D

\begin{tabular}{|c|c|c|c|c|c|}
\hline & (1) & (2) & (3) & (4) & \\
\hline Constant & $\begin{array}{l}-35.869 \text { * } \\
(19.861)\end{array}$ & $\begin{array}{r}-6.096 \\
(18.815)\end{array}$ & $\begin{array}{r}-5.246 \\
(18.644)\end{array}$ & $\begin{array}{r}-9.525 \\
(21.843)\end{array}$ & \\
\hline R\&D Employment & $\begin{array}{l}1.029 \text { ** } \\
(0.154)\end{array}$ & $\begin{array}{l}4.601 \text { ** } \\
(0.481)\end{array}$ & $\begin{array}{l}4.587 \\
(0.4784)\end{array}$ & $\begin{array}{r}1.267 \\
(0.175)\end{array}$ & ** \\
\hline R\&D Employment Squared & & $\begin{array}{l}-26.54 \\
(3.421)\end{array}$ & $\begin{array}{l}-26.377 \\
(3.387)\end{array}$ & & \\
\hline Plant Size (Empl) & $\begin{array}{l}0.382 \text { ** } \\
(0.051)\end{array}$ & $\begin{array}{l}0.215^{* *} \\
(0.054)\end{array}$ & $\begin{array}{c}0.220 \text { ** } \\
(0.0517)\end{array}$ & $\begin{array}{r}0.152 \\
(0.102)\end{array}$ & \\
\hline Plant Size Squared & $\begin{array}{l}-1.582 \\
(0.264)\end{array}$ & $\begin{array}{l}-1.388 \text { ** } \\
(0.251)\end{array}$ & $\begin{array}{l}-1.409 \\
(0.243)\end{array}$ & $\begin{array}{r}1.425 \\
(1.147)\end{array}$ & \\
\hline Plant Size Cubed & & & & $\begin{array}{r}-0.087 \\
(0.032)\end{array}$ & ** \\
\hline Sectoral R\&D Intensity & $\begin{array}{l}7.022 \text { ** } \\
(3.138)\end{array}$ & $\begin{array}{r}2.959 \\
(2.931)\end{array}$ & $\begin{array}{r}2.901 \\
(2.928)\end{array}$ & $\begin{array}{r}6.163 \\
(3.130)\end{array}$ & ** \\
\hline Graduate Share & $\begin{array}{l}2.868 \text { ** } \\
(0.813)\end{array}$ & $\begin{array}{c}1.761 \text { ** } \\
(0.761)\end{array}$ & $\begin{array}{l}1.777 \text { ** } \\
(0.759)\end{array}$ & $\begin{array}{r}2.772 \\
(0.807)\end{array}$ & ** \\
\hline Small Batch Production & $\begin{array}{l}-20.995 \text { * } \\
(16.890)\end{array}$ & $\begin{array}{l}-26.529 * \\
(15.57)\end{array}$ & $\begin{array}{l}-26.888 \text { * } \\
(15.517)\end{array}$ & $\begin{array}{r}-25.067 \\
(16.822)\end{array}$ & \\
\hline Large Batch Production & $\begin{array}{l}-52.664 \text { ** } \\
(18.085)\end{array}$ & $\begin{array}{l}-56.432 \text { ** } \\
(16.661)\end{array}$ & $\begin{array}{l}-56.819 \\
(16.604)\end{array}$ & $\begin{array}{r}-53.308 \\
(17.962)\end{array}$ & ** \\
\hline MNE Plant & & $\begin{array}{r}7.126 \\
(19.551)\end{array}$ & & $\begin{array}{r}-1.943 \\
(21.272)\end{array}$ & \\
\hline Adjusted $\mathrm{R}^{2}$ & 0.375 & 0.472 & 0.473 & 0.386 & \\
\hline$F()$. & 28.89 & 33.35 & 37.6 & 23.75 & \\
\hline Log Likelihood & -2060.2 & -2031.6 & -2031.7 & -2056.3 & \\
\hline
\end{tabular}

Note: The dependent variable is the unit cost of internal R\&D, i.e. the cost of internal R\&D per product innovation. Estimation is restricted to those companies undertaking internal R\&D only. Figures in brackets are standard errors. ** denotes that a coefficient is significant at the five percent level. * denotes significance at the 10 per cent level. 


\section{References}

Acs, Z J and Audretsch, D B 'Innovation in Large and Small Firms', American Economic Review, 1988, 78, pp. 678-90.

Acs, Z and Audretsch, D B 'R\&D, Firm Size and Innovative Activity', in Acs, Z J and Audretsch, B D, eds, Innovation and Technological Change. Hemel Hempstead: Harvester Wheatsheaf, 1991.

Audretsch, D B Innovation and Industry Evolution. Cambridge, Mass: MIT Press, 1995.

Audretsch, D B and Feldman, M P 'R\&D Spillovers and the Geography of Innovation and Production, American Economic Review, 1996, 86, pp. 630-9.

Audretsch, D B, Menkveld, A J and Thurik, A R 'The Decision Between Internal and External R\&D', Journal of Institutional and Theoretical Economics, 1996, 152, pp. 51730.

Birkinshaw, J and Hood, N, eds., Multinational Corporate Evolution and Subsidiary Development. Basingstoke: Macmillan, 1998.

Dolton, P J, Makepeace, G H and Van Der Klaauw W 'Occupational Choice and Earnings Determination: the Role of Sample Selection and Non-pecuniary Factors', Oxford Economic Papers, 1989, 41, pp. 573-94.

Egelhoff, W G Gorman, L and McCormick, S 'Using Technology as a Path to Subsidiary Development', in Birkinshaw, J and Hood, N, eds., Multinational Corporate Evolution and Subsidiary Development, Basingstoke: Macmillan, 1998.

Geroski, P 'Innovation, Technological Opportunity, and Market Structure', Oxford Economic Papers, 1990, 42, pp. 586-602. 
Greene, W H Econometric Analysis. New York: Macmillan, 1997.

Hall, P Innovation, Economics and Evolution. Hemel Hempstead: Harvester Wheatsheaf, 1994.

Harris, R I D and Trainor, M 'Innovations and R\&D in Northern Ireland Manufacturing: a Schumpeterian Approach’ Regional Studies, 1995, 29, pp. 593-604.

Hay, D A and Morris, D J Industrial Economics and Organisation, $2^{\text {nd }}$ ed. Oxford: Oxford University Press, 1991

Hertog, R G J den and Thurik A R 'Determinants of Internal and External R\&D: Some Dutch Evidence’ De Economist, 1993, 141, pp. 279-89.

Klein, B, Crawford, A and Alchian, A 'Vertical Integration, Appropriable Rents and the Competitive Contracting Process' Journal of Law and Economics, 1978, 21, pp. 297-326.

Jaffe, A B 'Technological Opportunity and Spillovers of R\&D: Evidence from Firms' Patents, Profits and Market Value’, American Economic Review, 1986, 76, pp. 948-99

Love, J H 'The Transaction Cost Theory of the (Multinational) Firm: a Note', Journal of Institutional and Theoretical Economics, 1997, 153, pp. 674-81.

Love, J H and Roper, S 'The Determinants of Innovation: R\&D, Technology Transfer and Networking Effects’ Review of Industrial Organization, 1999, 15, pp. 43-64.

Maddala, G S Limited-Dependent and Qualitative Variables in Econometrics. Cambridge: Cambridge University Press, 1983.

Masten, S, Meehan, J and Snyder, E 'The Costs of Organization' Journal of Law, Economics and Organization, 1991, 7, pp. 1-25. 
Mowery, D C 'The Development of Industrial Research in US Manufacturing', The American Economic Review, 1990, 80, pp. 345-9.

Niosi $\mathrm{J}$ 'The Internationalization of Industrial R\&D: from Technology Transfer to the Learning Organization’ Research Policy, 1999, 28, pp. 107-17.

Roper, S, Ashcroft, B, Love, J H, Dunlop, S, Hofmann, H and Vogler-Ludwig K Product Innovation and Development in UK, Irish and German Manufacturing. Queen's University of Belfast/University of Strathclyde, Belfast and Glasgow, 1996.

Roper, S 'Product Innovation and Small Business Growth: a Comparison of the Strategies of German, UK and Irish Companies', Small Business Economics, 1997, 9, pp. 523-37.

Shelanski, H A and Klein, P G 'Empirical Research in Transaction Cost Economics: a Review and Assessment', Journal of Law, Economics and Organisation, 1995, 11, pp. 335-61.

Teece, D 'Technological Change and the Nature of the Firm' in G Dosi et al, eds., Technical Change and Economic Theory. London: Pinter, 1988.

Ulset, S 'R\&D Outsourcing and Contractual Governance: and Empirical Study of Commercial R\&D Projects', Journal of Economic Behavior and Organization, 1996, 30, pp. 63-82.

Veugelers, R ‘Internal R\&D Expenditures and External Technology Sourcing’, Research Policy, 1997, 26, pp. 303-16.

Veugelers, R and Cassiman, B 'Make and buy in innovation strategies: evidence from Belgian manufacturing firms’, Research Policy, 1999, 28, pp. 63-80. 
Williamson, O E 'Transaction Cost Economics: The Governance of Contractual Relations' Journal of Law and Economics, 1979, 22, pp. 3-61. 